УДК 81'22: 398.21(045)

https://doi.org/10.31548/philolog2020.02.031

\title{
ARCHETYPICAL BACKGROUND OF MAGICAL HELPERS IN ENGLISH AND UKRAINIAN FAIRY TALES
}

\author{
K. V. STEPANENKO, PhD Candidate: General Linguistics \\ Kyiv National Linguistic University \\ E-mail: stpnnkkaterinaukkr@gmail.com \\ http://orcid.org/0000-0002-1553-4350
}

\begin{abstract}
Fairy tale is a form of literature where each element is meaningful and connected with other elements of the narrative forming together a solid unit to reflect the image of reality, structure the knowledge about human experience, the world and the place of a human in it. Therefore, tale is a cognitive construct to reveal the worldview, cultural symbols and codes which are systematic. Folklore is one of the genres that represents cultural unconscious. The paper uses the notion of an archetype suggested by K.G. Jung to apply for the study of cultural archetypes. The basic archetypes of the key elements of Water, Fire, Earth, and Air which can be found in both English and Ukrainian fairy tales, are revealed through different magical helpers which are objects, natural phenomenons and creatures belonging to different fairy tale worlds. These magical things and creatures are considered as helpers on the way of a character towards his transformation that is equal to reaching the different life stage, rebirth, improvement etc. English fairy tales are closely connected with Christian beliefs, while Ukrainian folk narrative reflects pagan images of the natural elements and magical objects respectively.
\end{abstract}

Key words: archetype, magical helper, magic world, transformation, cognitive aspect.

Introduction. Fairy tale is a genre of literature which is of high importance for understanding national background. Each nation has a set of images about the world reflected in archetypes. This study shows how key universal archetypes are revealed in magical helpers which are the structural units of fairy tale narrative. Magical helpers are the things or creatures which are to assist the characters to find their course among various fairy tale worlds, and achieve rebirth or transformation on their way.

Recent researches and publications. Numerous studies are dedicated to identify the notion of archetype within the scope of literature. Deep meaning of archetypes is paid significant attention by J. Mills [16] who studies them based on Jungian approach. N. Gavkalova, O. Amosov [13], M. L. von Franz [11] stress that archetypes have signifycant influence on social transformations. Aiming to identify general or specific archetypical notions, L. B. Ronald [7] discusses how archetypes are reborn in fairy tales, N. I. Matveichuk [1], O.Tykhovska [4],
M.Yu.Sevetynova [2], dedicate their studies to show the value of archetype for culture and stress that archetypes are reflected in language. Archetypical analysis is widely implemented to study works of literature by N. K. Kravchenko [14], and N. V. Slukhai [3].

Since archetypes in our discussion are inseparable form magic helpers, it's important to point out that 'magic' in literature as a notion is questioned by numerous researches who focused on studying the imaginary, unreal words and creatures, and magic in the folk narrative in particular (J. G. Frazer [12], T. Longinovic [15], R. Bottigheimer [7], B. Copenhaver [9], D. Fang [10]). Tales of this kind depict magic heroes, objects, and animals in attempt to illustrate the structure of the imaginary world. Additionally, E. F. Jannidis, R. Schneider, E. M. Segal [9] study characters, fairy tale worlds and imaginary beings in literature in their collective research.

The purpose of this article is to identify general and ethno-specific magical helpers represented by universal archetypes in 
English and Ukrainian fairy tales.

Data and methods. The research data base on the tales, which are identified in the ATU Folktale and Motiff Index [1] as 'Tales of Magic, i.e. containing magical things, objects, events. To select the culturally significant elements, analysis and synthesis have been used. On the second sage, the identified elements are subjected to archytypical method.

Results. Fairy tales also known as 'Tales of Magic', wonder tales or magic tales are regarded as a special group in the fairy tale collections as they not only include enchantment, magic things and creatures, but also represent archaic beliefs of the naïve image of the world. Therefore, this type of folklore reflects the most valuable community notions which this research intends to explain through key archetypes. Even though the folktales of different countries may not seem to have a lot of similar traits, when analyzing key archetypes it can be seen that they have much in common in terms of symbols and ancient beliefs while reflecting symbols ideas or elements through different concepts.

Archetypes illustrate key stages of life such as birth, initiation, marriage, death, due to which change of the condition, look or status of the hero happens. Each of these stages indicates a specific new "world» in the life of a character. Therefore, one of the special traits of the fairy tale is differentiation between "this» and "that» world, «known» and «unknown», where the archetypes are reflected in real or metaphorical worlds. The "otherworld" is similar to the real one with the only difference that specific representative creatures or objects are found there (which may, however, sometimes migrate between the worlds). The motif of transformation is archetypical itself which is usually seen through the way the plot of the tale is built.

The notion of an archetype and psychological archetype in particular, was coined and introduced into science by K.G.Jung [5], who explained it using mythology as illustrative material. Having analyzed numerous myths the philosopher found out that there are units which are not realized, however, can be traced in mind. These small units are the unconscious images which determine behaviour of a specific individual and the culture that the person belongs to as well. He believed that fairy tales are a unity of collective wisdom that builds connections between generations.

Later, the term «archetype» was applied to study not only psychological, but also cultural and linguistic phenomena. Unlike K.G.Jung, S.Thompson [17] viewed archetypes as key motifs or subjects.

However, in addition to characterising archaic notions, archetypes can be the basement for developing new concepts due to their multiple-level structure and ability to produce chains of meanings.

Even though the archetypes exist in collective unconscious, they can be traced in the text, where they are considered as dominants for a particular culture, that is, as its ethno-specific characteristics. Archetypes are the symbols that enable the study of culture through generations. These are the symbol that people tend to highlight in literature in particular.

It is important to admit the binary nature of the archetype, since the same archetype is identified in ambivalent concepts, i.e. Water can be both deathly and curing, and the main archetypical model in the folk narrative relies on the 'birth/rebirth' principle.

The universal archetypes of Water, Fire, Earth, and Air are found in the fairy tales belonging to both English and Ukrainian linguocultures, however, the way they appear through objects in the texts, differ.

Water is the basic world-construction element, it belongs to sacred liquids that denotes real or metaphorical beginning of life, rebirth, death i.e. transition between the fairy tale worlds.

Water is believed to be sacred in both cultures, however in English tale it is mostly depicted like Holy water, while in Ukrainian tales it is shown as living water. In the tale 
«Devil, Snake and old Children» we can see that living water from the stream brings a man back to life. Thus, water is regarded as magic, and can be found in other tales like «Flying Ship» where the characters set off for a journey full of challenges in order to find magic living youthful water in a faraway land. Also in the tale "About the Shooter» milk possesses the same magic properties as water and the one who is brave to swim in the boiling milk, will be granted youth.

In English tales, Water is transformed into the Holy water, for example, when a Saint man prayed on the well, water acquired curative and protective properties "Saint now prayed that all children baptised in the waters of this well might be protected against the hangman and his hempen cord» («The Well of Saint Lundgvan»), and the well in this regard is considered a magic helper since it contains sacred item and helps to perform the transition from danger to safety, from illness to health.

In contrast, water can be destroying. In the English tale «Bomere Pool» it is a tool for punishing nonbelievers and floods their village "the inhabitants were a wicked race, who mocked at God and His priest ... The old priest earnestly warned them that God would punish such wickedness as theirs by some sudden judgment... when a flood of water dashed into the church, ....and the mere, which had burst its mountain barrier, occupied the hollow in which the village had stood». This is the example of water acting as a 'destructive magic helper'.

From the cognitive point of view, traditional symbols are formed through the projection of archetypical symbol onto the essence of the object. Water is shown as far, magic, strange, and magical helpers that are related to Water can be milk, holy water, lakes, rivers, wells. Thus water is understood through archetypical patterns "water as life» and «water as death».

Fire, as well as Water, belongs to key elements of the unconscious and is reflected in the folklore. Fire in the fairy tale symbolizes both holy light and the underworld. It signifies various motifs like life and death, destruction and burning, rebirth, underworld and holy fire. This element is binary as well, since fire has protective amulet power, and at the same time can be destroying.

In Ukrainian fairy tales Fire has a quality to improve and purify through burning. For example, a lazy boy burnt and reborn three times changed into a better version of a human as a result of this ritual («Oh»). When the lad in Ukrainian tale wanted to kill a witch, she begged him not to do so since she is a pure soul purified by fire («The Silk Country»). In a tale "The Tree up to the Sky» we can see how fire grants power: as soon as the boy fed a horse with it, the horse became strong enough to break the chains and escape from the giant. On the contrast, fire is destroying if applied to infernal creatures: if one burns the Book of the Giant's Life, this indicates the giant's death («A Branch-Girl»).

In Ukrainian tales fire is also connected to the cosmogenic image of the Sun, which posesses human-like traits, has a mother and home. The girl in a tale "About seven Brothers-Crows and their Sister» manages to make her way to the Sun's home, ask the Sun's mother for advice, receive permission to interact with the Moon and the Wind. Therefore it is the key solar element.

Fire in English folklore, if it is not holy fire from the church, is destroying and not merciful as an attribute of the creatures from the underworld («The Haunted Hare», "The Demon Tregeaeagle»), or symbolizes the end of life without a chance for rebirth («The Witch and the Toad»).

In addition to that, chimney is viewed as a portal for the evil forces in English tale "this time a second giant came in at the door... but the legs walked on to the fire and went straight up the chimney» ("The Golden Ball»), thus if one looks up the chimney, he / she can be taken to the otherworld.

It was noticed that in Ukrainian tales fire is divided onto "female fire» and «male fire». Female fire is usually burnt and taken care of by a female, it is located within the house and a woman watches it. Also it can

(C) K. V. Stepanenko

«International journal of philology» | «Міжнародний філологічний часопис» Vol. 11, № 2, 2020 
be found in domestic objects: oven in Ukrainian tale and fireplace in English tale. In Ukrainian folklore if a girl tales care of the oven, she is rewarded with special gift, i.e. magic objects, future happy life («Grandfather's Daughter and Grandmother's Daughter»). «Male fire» is found outside the house, it had to be lit and taken care of by men mostly "At night we should watch fire for the animals not to attack us» («About the Mount that Reached the Sky») in order not to be captured by animals or creatures from the otherworld.

In English tales domestic fire is associated with safety and burning the fire is a responsibility of a girl: "She had to sweep the floor, keep the house clean and tidy, the fire bright and cheery» ("The Two Sisters»), "the girl swept, and dusted, and made up the fire» («Tree of Mine»). Cosiness of domestic fire in English tales can be seen in "The Golden Snuff Box» ("so the maid-servant at once called him in to the fireside»), or "The True History of Sir Thomas Thumb» ("His mother put him to rest in a walnut shell by the fire»), here fire is a helper to transit from danger of the outside world to the safety from evil forces granted by the fire. However, outside the safe indoor environment Fire is a characteristic of infernal creatures.

Fire is reflected in cultural patterns, for example with animals like snake in Ukrainian tale since it breathes with fire ( «Ivan the Son of the Peasant»); dogs («Specter-Dogs») and horses («The Demon Tregeaggle») in English folklore as they have fiery eyes.

Thus the archetype of Fire is manifested by domestic fire, fire in the forest, oven, fireplace, chimney, sun. In addition to that it is associated with the creatures related to the infernal world. Each of these helpers performs functions to assist the character on the way to the upper or lower worlds which equals to transition from life to death.

Earth is also a constituent part of the world-creation group of archetypes since it marks the opposition «heavenunderworld», and functions as an element of the «up-down» opposition. For example, if the character is in a deep pit, Earth is understood as "upworld", if the opposition to Earth is Heaven, then Earth is the «underworld».

Archetype of Earth can be shown through objects which symbolically represent the «up-down» opposition: a top of a tree, a top of the mount (in Ukrainian tales), the top of the Mount, the high altar, the roof (in English tales).

However, horizontally Earth is an element of an opposition "close-far», since characters are often sent to search for happiness, treasure, or rebirth in the faraway lands ("Youthful Water», «Magic Lantern»).

In Ukrainian folklore Earth is personified: "The earth swallowed» («земля проковтнула») («The Tree up to the Sky»), "the earth sighted» («земля тільки стогне») («Kyrylo the Skinner»); "the earth was shaking» («земля тремтіла») («The Wise Ivanko»). The Earth can help to read the future events like appearance of a dragon or a witch. If the character puts his ear to the Earth, he will hear the events from far away («The Flying Ship»).

In the English folklore, Earth is mostly shown as a transition level, or belongs to the underworld: "the earth concealed its dead" («The Story Of Saint Kenelm»), and all what is hidden in the Earth or underground, thus denoting the lower world: "beautiful corpse... was placed in the earth» («The Fairy Funeral»), "the spirits of the earth» («The Lord Of Pengerswick An Enchanter»), "a handful of earth from the churchyard» awakens the spirits («He Fell On His Knees»). The creatures living deep under Earth usually embody danger for humans: "small people underground». If a girl can see such creatures, it means that she broke the master's prohibition and saw what was not supposed to be seen by a human since it belongs to the underworld. («The Adventure Of Cherry Of Zennor»). An infernal creature may also exist among people, however, it still belongs to the underworld " $\mathrm{I}$ am not art inhabitant of the earth» («The Hunted Hare»). 
If something is potentially dangerous, it is described as "unearthly»: unearthly laughter («The Parson and Clerk»), unearthly sounds... unearthly clanging («Kentsham Bell»), unearthly character («The Ghost of Rosewarne»).

Thus, in Ukrainian folklore the Earth is depicted as a living being that the hero interacts with, as a stage for reaching both upper world and underworld. However, in the English tales Earth is a place for numerous underworld infernal creatures and the magic is mostly revealed by the creatures, inhabitants of Earth or underearth. The magic helpers that correlate with the archetype of Earth are creatures which are usually hidden by Earth or underground. In Ukrainian folk narrative Earth is a helper itself due to its personification.

One more key archetype is Air which is both a helper and a destroying magic phenomenon. Air is a place for both souls and infernal creatures. The change of the condition of Air predicts the forthcoming dangerous events: strong winds indicate the appearance of a snake in numerous Ukrainian fairy tales ("How the Snakes Stole three Sisters», "How the King got the Horns on his Head»). The same correlation is noticed in English folklore where the change of the condition of air (i.e. whirlwind) indicates appearance of the evil («The Lady with the Lantern») or demon («The Demon Tregeagle», "The Witch of Fraddam and the Enchanter of Pengerswick»). However, the specific quality which is a characteristic of Air in the English tales is the aroma of air, i.e.it can be perfumed and related to the blooming spiritually joyful garden («The Adventure of Cherry of Zennor»), or it may have a strong sulphurous scent that associates the place with the underworld («The Hunted Hare»).

Air is a personificated element in Ukrainian folklore since it is embodied by characters like Wind, Wind's mother («The Magic Box», "The Magic Fire»). They are

\section{Список використаних джерел}

1. Матвейчук H. I. Відображення архетипів української культури в народних казках. Рівне: Вісник Національного shown human-like, moreover, people approach them, interact with them, cooperate, ask for advice, thus Air has man-like characteristics.

In both linguocultures Air is a place where different creatures exist, however in English tales they are mostly ghosts and spirits, and in Ukrainian tales Air is a location for birds which are considered magic helpers that transfer characters between the worlds, indicate where the hidden treasure is. For example, in Ukrainian tale "Kotyhoroshko» the bird takes the boy from the underworld to the surface, thus, it is symbolically related to Heaven. Birds also represent souls, totem reincarnation: in the tale "The Girl from the Apple», the girl took off her dress, jumped into the water and turned into a bird, which enables her to escape from evil.

Therefore the archetype of Air is reflected in natural phenomena like wind or whirlwind. Additionally, creatures which are inhabitants of Air are considered as otherworld creatures (i.e. magical), they are souls and spirits in English fairy tales and birds in Ukrainian tales.

Conclusions and discussion. Fairy tales reflects the basic archetypes; however they are depicted in a different way and through various objects. Since archetypes are found in all cultures, fairy tale is a rich source for revealing them as language of fairy tales absorbed the prototypes of key cultural concepts. Moreover, with time, archetypes are revealed in their invariants. Ukrainian tale is connected with archaic beliefs and cosmogonic mythology. The elements in Ukrainian tales have animatic traits and natural objects are treated like «alive» preconcepts from pagan beliefs. English tales manifest Christian beliefs. At the same time, British folklore is mystical due to the presence of various fairies, witches, ghosts and small people in the folk tales.

університету водного господарства та природокористування. 2009. Вип. 3 (47). 4. 3. С. $231-236$.

2. Северинова М. Ю. Значення та

(C) K. V. Stepanenko

«International journal of philology» | «Міжнародний філологічний часопис» Vol. 11, № 2, 2020 
роль архетипів у етнонаціональній культурі. Мистецтвознавство. Вісник НАКККіМ. 2012. №2. С.125-128.

3. Слухай Н. В. Категоріальні архетипи мови міфопоетичної традиції язичників i християн: спроба зіставлення. Вісник Київського інституту «Слов'янський університет». 2001. С. 169-179.

4. Тиховська О. Архетипний зміст українських чарівних казок. Слово: Літературознавство і компаративістика. 2013. № 2. C.42- 48.

5. Юнг К. Г. Архетип и символ. Москва: Канон+РООИ «Реабилитация». 2016. 336 c.

6. Aarne-Thompson-Uter Classification of Folk Tales. 24 May 2020. Available at: https://sites.ualberta.ca/ urban/Projects/En glish/Content/ATU_Tales.htm

7. Bottigheimer R. Magic Tales and Fairy Tale Magic. UK: Palgrave Macmillan. 2014. 208 p.

8. Boyer Ronald L. The Rebirth Archetype in Fairy Tales: a Study of Fitcher's Bird and Little Red Cap. 24 May 2020. Available at:

http://societyforritualarts.com/coreopsis/th e-rebirth-archetype-in-fairy-tales/

9. Copenhaver B.P. Magic. In Western Culture. Cambridge: Cambridge University Press. 2015. 612p.

10. Eder J. \& Jannidis F. \& Schneider R. Characters in Fictional Worlds: Understanding Imaginary Beings in Literature, Film, and Other Media Berlin: Walter de Gruyter. 2010. 596 p.

11. Fang D. Magical Objects in Victorian Literature: Enchantment, Narrative Imagination, and the Power of Things (Dis.PhD). Nashville, Tennessee. 2015. 197p.

12. Franz, M.-L. von. Archetypal patterns in fairy tales (studies in Jungian psychology by Jungian analysts). Toronto: Inner City Books. 1997. 191p.

13. Frazer, J. G. The Golden Bough: A Study in Magic and Religion (abridged ed.). New York: Cosmo Inc. 2005. 732p.

14. Gavkalova N. L., Amosov O. Yu. The Influence of Archetypes on Social Transformations. Публічне урядування.
2018. № 4 (14). 08 May 2020. Available at https://cyberleninka.ru/article/n/the-influenceof-archetypes-on-social-transformations

15. Kravchenko N. K. Pantelejmon Kulish's Symbolic Imagery in Comparison to the Cristian and Mythological Archetypal Symbolism (Based on the Story «Granny from the Other World». Міжнародний філологічний часопис. Київ : Мілленіум. 2019. Vol. X (10). № 1. C. 14-18.

16. Longinovic $T$. The Magic of the Slavic Folk Tale. San Diego: Cognella Academic Publishing. 2018. 314p.

17. Mills J. The Essence of Archetypes. International Journal of Jungian Studies. 2018. Vol. X (10). Iss.3. P.199-220.

18. Thompson S. The Folktale. University of California Press. 1951. P. 455456.

\section{References}

1. Aarne-Thompson-Uter. Classification of Folk Tales: веб-сайт: 24 May 2020 Available at: https://sites.ualberta. ca/ urban/ Projects/English/Content/ATU_Tales.htm

2. Bottigheimer R. (2014). Magic Tales and Fairy Tale Magic. UK: Palgrave Macmillan. 208 p.

3. Boyer Ronald L. The Rebirth Archetype in Fairy Tales: a Study of Fitcher's Bird and Little Red Cap. 24 May 2020. Available at: http://societyforritualarts. com/coreopsis/the-rebirth-archetype-in-fairytales/

4. Copenhaver B.P. (2015). Magic. In Western Culture. Cambridge: Cambridge University Press. 612p.

5. Eder J. \& Jannidis F. \& Schneider R. (2010). Characters in Fictional Worlds: Understanding Imaginary Beings in Literature, Film, and Other Media. Berlin: Walter de Gruyter. 596 p.

6. Fang D. (2015). Magical Objects in Victorian Literature: Enchantment, Narrative Imagination, and the Power of Things. (Dis.PhD). Nashville, Tennessee. 197p.

7. Franz, M.-L. von. (1997). Archetypal patterns in fairy tales (studies in Jungian psychology by Jungian analysts). Toronto: Inner City Books. 191p.

8. Frazer, J. (2005). The Golden Bough: a Study in Magic and Religionn

(C) K. V. Stepanenko

«International journal of philology» | «Міжнародний філологічний часопис» Vol. 11, № 2, 2020 
(abridged ed.). New York: Cosmo Inc. 732p.

9. Gavkalova N. L. \& Amosov O. Yu. (2018). The Influence of Archetypes on Social Transformations. Публічне урядування. № 4 (14). 08 May 2020. Available at: https://cyberleninka.ru/article/n/the-influenceof-archetypes-on-social-transformations.

10. Jung K.G. (2016). Arhetyp i symvol. Moskow : Kanon+ROOI "Reabilitatsiya". $336 \mathrm{c}$.

11. Kravchenko N. K. (2019). Pantelejmon Kulish's Symbolic Imagery in Comparison to the Cristian and Mythological Archetypal Symbolism (Based on the Story "Granny from the Other World». International Journal of Philology. Kyiv: Milenium. Vol. X (10). № 1. P. 14-18.

12. Longinovic T. (2018). The Magic of the Slavic Folk Tale. San Diego: Cognella Academic Publishing. 314 p.

13. Matveychuk N. I. (2009). Vidobrazhennia archetypiv ukrainskoi kultury v narodnykh kazkah. Rivne: Visnyk
Natsionalnoho universytetu vodnoho hospodarstva ta pryrodokorystuvannia. Vyp. 3 (47) Ch. 3. P. 231-236.

14. Mills J. (2018). The Essence of Archetypes. International Journal of Jungian Studies. Vol. X (10). Iss.3. P. 199220.

15. Severymova M. Yu. (2013). Znachennia ta rol archetypiv v etnonatsionalniy kulturi. Mystetstvoznavstvo. Visnyk NAKKiM. 2012. №2. P.125-128.

16. Slukhai H. V. (2001). Katehoruialni arhetypy movy mifopoetychnoi tradytsii yazychnykiv i hrystyian: sproba zistavlennia. Visnyk Kyivskoho instytutu "Slovianskyi universytet". P. 169-179.

17. Thompson S. (1951). The Folktale. University of California Press, P. 455-456.

18. Tykhovska O. (2013). Arhetypnyi zmist ukrainskyh charivnyh kazok. Slovo: Literaturoznavstvo i komparatyvistyka. P.42- 48.

\section{АРХЕТИПНЕ ПІДґ'РУНТЯ ЧАРІВНИХ ПОМІЧНИКІВ У АНГЛІЙСЬКИХ ТА УКРАЇНСЬКИХ ЧАРІВНИХ КАЗКАХ К. В. Степаненко}

Анотація: Чарівна казка - це форма літератури, де кожен елемент є значимим та поєднаним із іншими елементами наративу, що утворюють цілісний конструкт, який відображає уявлення про реальність, структурує знання про людський досвід, світ та місце людини в ньому. Таким чином, казка - че когнітивний конструкт, що відображає світогляд, культурні символи та коди які формують систему. Фольклор це один із жанрів, який репрезентуе неусвідомлене в культурі. У статті використовується поняття «архетипу» введене К.Г. Юнгом для дослідження культурних архетипів. Базовими архетипами ключових сихій $є$ Вода, Вогонь, Земля, Повітря, які знаходимо у анелійських і в українських казках втіленими у різних чарівних помічниках, які можуть бути предметами, природніми стихіями, та створннями які належать до інших казкових світів. Такі чарівні предмети та істоти вважаються помічниками у житті героя на його шляху до іншого казкового світу, що є рівноцінним переходу на наступний життєвий етап, переродження, покращення, тощо. Англійські казки тісно пов»язані з християнськими віруваннями, у той час як український казковий наратив відображає язичницькі уявлення про сили природи та чарівних помічників, відповідно.

Ключові слова: архетип, чарівний помічник, чарівний світ, перетворення, когнітивний аспект. 